$44 \%$. His only treatment has been a 15-day course of primaquine followed by $100 \mathrm{mg}$. of proguanil daily. This is further evidence for a malarial cause of this syndrome and also for implicating the spleen in the plasma volume changes. The role of the spleen is also shown by a case of Felty's syndrome (Pengelly, 1966), in which a marked reduction in spleen size and plasma volume after corticosteroid therapy was found.

Not all patients with big spleen disease or idiopathic tropical splenomegaly respond to antimalarial therapy, and even for those cases which do respond long-term supervision may be impossible. In those patients with chronic abdominal pain, an enormous spleen, and gross dilution anaemia, splenectomy may be the treatment of choice. M. Paliwoda (personal communication, 1967) carried out 70 splenectomies for cases such as these in Uganda with an operative mortality of only $4.3 \%$, and though the follow-up data are incomplete the patients in general seem to have done well. However, the spleens are large, and good surgical technique with wide exposure is necessary. There is a danger of overtransfusing a hypervolaemic patient and also the added risk in the tropics of patients being particularly prone to infection after splenectomy. Fatalities from $P$. falciparum after splenectomy have occurred in West Africa (Watson-Williams, personal communication). In this series, postoperatively, the patients all registered high antibody levels to malaria and two developed a high brucella antibody titre; however, none seem to have suffered from significant clinical malaria. Against these dangers must be sef the marked improvement in the well-being of these patients, who were able to return to doing a normal day's work after splenectomy.

\section{Summary}

The clinical and haematological effects of splenectomy on five Ugandan patients with "big spleen disease" were studied
15 months after operation and the results compared with those obtained preoperatively.

All patients were symptomatically much improved and they all showed a marked improvement in their haemoglobin and P.C.V. levels. Before operation the patients had marked hypervolaemia and dilution anaemia, but after splenectomy the plasma volumes had returned to normal in three patients and in two were still slightly raised. One patient had developed evidence of myelofibrosis, but the others showed no marked change in liver biopsy appearances.

There were no untoward effects of splenectomy and no acute attack of malaria was described, though the malaria antibody titre had been maintained or raised.

We are grateful to Professors A. W. Woodruff, J. A. Tulloch, and W. A. Parson for their encouragement and criticism, and to Dr. G. Cook and Dr. D. Wykoff for their help in this study. Financial support was provided by the Leverhulme Trust, the World Health Organization, and the U.S. Army Medical Research and Development Command, Department of the Army, under Research Grant Number DA-MD-49-193-63-6101.

\section{REFERENCES}

Bowdler, A. J. (1967). Proc. roy. Soc. Med., 60, 44.

Cook, J., McFadzean, A. J. S., and Todd, D. (1963). Brit. med. F., 2, Dacie, J. V., and Lewis, S. M. (1963). Practical Haematology, 3rd ed. London.

Hamilton, P. J. S., Gebbie, D. A. M., Hutt, M. S. R., Lothe, F., and Wilks, N. E. (1966). Brit. med. Ұ., 2, 548. (1965). Clin. Sci., 29, Leonard,

McFadzean, A. J. S., Todd, D., and Tsang, K. C. (1958). Blood, 13, 524.

Pengelly, C. D. R. (1966). Brit. med. Y., 2, 986.

Richmond, J., Donaldson, G. W. K., Williams, R., Hamilton, P. J. S., and Hutt, M. S. R. (1967), Brit. F. Haemat. In press.

Voller, A. (1964). Bull. Wld Hith Org., 30, 343.

Weinstein, V. F. (1964). Lancet, 2, 218.

Williams, R., Parsonson, A., Somers, K., and Hamilton, P. J. S. (1966). Ibid., 1, 329. reticulocyte count is usual, and studies with radiochromiumlabelled cells demonstrate a shortened red cell life-span with evidence of excessive red cell destruction in the enlarged spleen (Pryor, 1967b). However, the main cause of the low haemoglobin value is a greatly expanded plasma volume, which may be more than twice the normal value.

A few individuals complain of symptoms of anaemia or pain and discomfort due to the size and weight of the spleen. Splenectomy has been performed in 15 patients who had disabling symptoms, and the results form the basis of this report.

\section{Methods}

Selection of Patients.- Twelve of the 15 patients requested splenectomy and the other three were similar patients with disabling symptoms. Twelve patients were from the Watut Valley and the remainder from villages in the Lae medical region. Eleven were males and four were females aged from 10 to 45 years (Table I). In each case the spleen was enlarged to below the umbilicus and in nine cases it extended into the right iliac fossa. All had an enlarged liver with a smooth firm 
edge. Ten patients had precordial systolic murmurs and 10 had raised jugular venous pressures. Less frequent signs were dependent oedema, leg ulceration, and mild jaundice. In all cases chest $x$-ray examination showed moderate enlargement of the heart with prominent pulmonary vascular markings.

Laboratory Techniques.-Standard haematological techniques were used (Dacie and Lewis, 1963). Radiochromium-labelled red cell studies were carried out by a modification of the method of Crawford and de Gruchy (1958). Plasma volume was measured with radioiodine $\left({ }^{131} \mathrm{I}\right)$-labelled human serum albumin (Veall and Vetter, 1958).

\section{Results}

\section{Haematological Findings}

The preoperative haematological findings are recorded in Table I. All patients were anaemic, with haemoglobin values ranging from 4.8 to 11.1 (mean 7.3 ) g./100 ml. Reticulocyte counts ranged from 6.6 to 23.3 (mean 11.3 ) \% and white cell counts from 1,400 to 5,500 (mean 3,700 )/cu. mm. All had thrombocytopenia, platelet counts ranging from 21,000 to 117,000 (mean 54,000)/cu. mm.

Various measurements with radioactive isotopes were performed preoperatively on 12 individuals (Table II). Red cell survival was measured in six subjects, ${ }^{51} \mathrm{Cr}$-labelled autologous red cells being used. The half-life ranged from 9 to 19 (mean 13) days, the normal range in New Guinea natives without splenomegaly being from 25 to 30 days (Pryor, 1967b). Despite the low haemoglobin values, the red cell volume measured with ${ }^{31} \mathrm{Cr}$-labelled red cells was normal or raised, the volumes in 12 subjects ranging from 24.0 to 51.2 (mean 35.5 ) $\mathrm{ml} . / \mathrm{kg}$. The normal range in New Guinea natives is similar to that in Caucasians-that is, 23 to $35 \mathrm{ml} . / \mathrm{kg}$. (Pryor, 1967b). Plasma volume measurements with ${ }^{131} \mathrm{I}$-labelled albumin in nine subjects gave high values ranging from 76.5 to 115.0 (mean 93.3) $\mathrm{ml} . / \mathrm{kg}$., the normal range being 40 to $50 \mathrm{ml} . / \mathrm{kg}$. (Dacie and Lewis, 1963).

\section{Preoperative Management}

During investigations in hospital the patients received a course of chloroquine $(600 \mathrm{mg}$. of chloroquine base followed by $300 \mathrm{mg}$. on the first day, $300 \mathrm{mg}$. daily for two further days, and $300 \mathrm{mg}$. weekly), ferrous sulphate $300 \mathrm{mg}$. three times daily, and a course of $5 \mathrm{~g}$. of bephenium hydroxynaphthoate (Alcopar) daily for three days. Patients were also given individual treatment such as diuretics for oedema and antibiotics for urinary or chest infections. In view of the increased blood volume, transfusions of packed red cells were given to achieve a haemoglobin level of about $9 \mathrm{~g} . / 100 \mathrm{ml}$. only. Eleven patients received an average of 4 units of packed cells ( 1 unit being equivalent to 400 to $500 \mathrm{ml}$. of whole blood) and four received none. The packed cells were given within two days of operation, since transfused cells have a short survival time in these patients and the haemoglobin level falls quickly after transfusion (Pryor, 1967a).

\section{Operation}

The peritoneal cavity was opened through an abdominal incision and at least $200 \mathrm{ml}$. of clear fluid was found in each case. The liver was enlarged in all, with prominent left lobe enlargement in two cases. The splenic blood vessels were large and not tortuous, curving down over the tail of the pancreas to reach the large splenic hilum. A systolic thrill was palpable over the vessels in two cases, one of which had had an audible bruit over the spleen before operation. Adhesions between the spleen and adjacent parts proved a major difficulty only once (Case 11). Splenic vein pressures were measured at operation in five cases with a simple glass manometer filled with sterile isotonic sodium citrate solution. The results ranged from 12 to 20 (mean 18) cin., normal values being from 4 to $19 \mathrm{~cm}$. (Atkinson and Sherlock, 1954).

Considerable shrinking of the spleen followed ligation of the splenic artery, and this facilitated the subsequent dissection and delivery of the organ, also producing an autotransfusion of

TABLE I.-Results of Routine Haematological Tests Before and After Splenectomy in 16 Cases of Tropical Splenomegaly

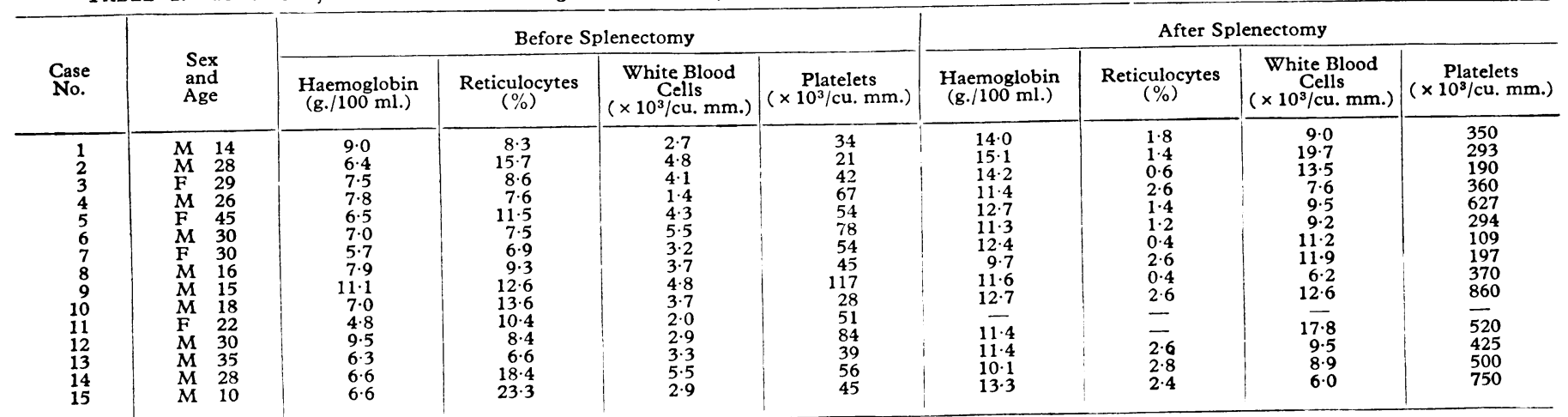

TABLE II.-Results of Red Cell Survival and Blood Volume Measurements Before and After Splenectomy for Tropical Splenomegaly

\begin{tabular}{|c|c|c|c|c|c|c|c|c|c|}
\hline \multirow[b]{2}{*}{$\begin{array}{l}\text { Case } \\
\text { No. }\end{array}$} & \multicolumn{4}{|c|}{ Before Splenectomy } & \multicolumn{5}{|c|}{ After Splenectomy } \\
\hline & $\begin{array}{c}\text { Red Cell } \\
\text { Survival } \\
\left.\text { ( } \frac{1}{2} \text { Cr. days }\right) \\
\end{array}$ & $\begin{array}{l}\text { Red Cell } \\
\text { Volume } \\
\text { (ml./kg.) }\end{array}$ & $\begin{array}{c}\text { Plasma } \\
\text { Volume } \\
\text { (ml./kg.) }\end{array}$ & $\begin{array}{c}\text { Total Blood } \\
\text { Volume } \\
\text { (ml./kg.) } \\
\end{array}$ & $\begin{array}{l}\text { Time After } \\
\text { Operation } \\
\text { (weeks) }\end{array}$ & 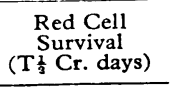 & $\begin{array}{l}\text { Red Cell } \\
\text { Volume } \\
\text { (ml./kg.) } \\
\end{array}$ & $\begin{array}{l}\text { Plasma* } \\
\text { Volume } \\
\text { (ml./kg.) }\end{array}$ & $\begin{array}{c}\text { Total Blood } \\
\text { Volume } \\
\text { (ml./kg.) }\end{array}$ \\
\hline $\begin{array}{r}1 \\
2 \\
3 \\
4 \\
5 \\
6 \\
7 \\
8 \\
9 \\
9 \\
11 \\
12 \\
12\end{array}$ & $\begin{array}{l}14 \\
9 \\
13 \\
= \\
- \\
\frac{8}{19} \\
\frac{19}{15}\end{array}$ & $\begin{array}{l}41 \cdot 0 \\
26 \cdot 4 \\
40 \cdot 4 \\
34 \cdot 8 \\
24 \cdot 0 \\
37 \cdot 1 \\
34 \cdot 9 \\
39 \cdot 3 \\
51 \cdot 2 \\
32.5 \\
29 \cdot 3 \\
35 \cdot 4\end{array}$ & $\begin{array}{c}\bar{Z} \\
\overline{98.0} \\
76.5 \\
104.0 \\
105.4 \\
115.0 \\
80.5 \\
86.0 \\
87.6 \\
87.0\end{array}$ & $\begin{array}{l}\bar{Z} \\
\overline{\overline{1}} \\
132 \cdot 8 \\
100 \cdot 5 \\
141.1 \\
140.3 \\
154.3 \\
131.7 \\
118.5 \\
116.9 \\
122 \cdot 4\end{array}$ & $\begin{array}{c}\overline{2-8} \\
33-37 \\
47 \\
5 \\
3 \\
16-22 \\
4 \\
3 \\
9 \\
- \\
2\end{array}$ & $\begin{array}{l}\overline{25} \\
26 \\
= \\
\overline{30} \\
= \\
= \\
=\end{array}$ & $\begin{array}{l}\overline{25} \cdot 9 \\
29 \cdot 5 \\
= \\
\overline{29} \cdot 2 \\
= \\
\overline{30} \cdot 9\end{array}$ & $\begin{array}{l}\overline{64} \cdot 0 \\
59 \cdot 3 \\
66 \cdot 7 \\
63.0 \\
75.4 \\
58 \cdot 3 \\
97.0 \\
63.0 \\
68.8 \\
\overline{70} \cdot 2\end{array}$ & $\begin{array}{l}\overline{89 \cdot 9} \\
88 \cdot 8 \\
= \\
\overline{87} \cdot 5 \\
= \\
\overline{\overline{1} 1.1}\end{array}$ \\
\hline
\end{tabular}

* Where plasma volume was measured more than once after splenectomy, the last result is given. The other results may be seen in the Chart. 
blood at this stage of the operation. Operative blood loss was replaced by transfusion of whole blood so that the haemoglobin level immediately after operation was higher than before.

\section{Postoperative Complications}

Four patients required transfusion for postoperative bleeding, in two of whom re-exploration of the abdomen was carried out. In one (Case 2) further ligation of the splenic artery stopped the bleeding, and the other (Case 11) died after continuous bleeding from the diaphragm and liver, which had been densely adherent to the spleen. Wound infections occurred in five cases but did not cause serious morbidity. Three patients had chest infections in the postoperative period and one had malaria due to Plasmodium vivax six weeks after operation. Two patients had marked dependent oedema and ascites after operation, which gradually subsided over about eight weeks.

\section{Pathology of Spleens and Livers}

The spleens weighed 2,090 to 4,380 (mean 3,270) g. Even after removal as described, almost 1 litre of blood ran from the spleen in two cases when the clamps were removed from the vessels. The spleens were firm in consistency, with rounded edges and one or two distinct notches on the medial border. The capsules were normal except for some patchy thickening in three cases. The cut surface of the spleens was a uniform dark red; no infarcts were seen though one specimen showed a subcapsular scar. The Malpighian bodies were not visible.

Microscopical examination of the splenic tissue revealed greatly dilated sinuses with reticuloendothelial hyperplasia and marked erythrophagocytosis. There was atrophy of the Malpighian bodies, a paucity of fibre, and no malarial pigment.

In 11 patients microscopical examination of a wedge biopsy of the liver showed sinusoidal dilatation, Kupffer cell hyperplasia, and lymphocytic infiltration of sinusoids and portal tracts, but no cirrhosis. The morphology of these livers and spleens has been reported in detail by Pitney et al. (1967).

\section{Results of Splenectomy}

Four patients were well 14 to 18 months and four at two to nine months after operation. Only a short time had elapsed since splenectomy in two cases. One Watut patient died the day after operation from uncontrolled haemorrhage, as described above, and two males (Cases 8 and 13) died of acute illnesses in the village five and three months after operation, respectively. Two patients had malaria due to $P$. vivax four and six months after operation, and two others had pneumonia while under observation, four and eight months after operation. One man had acute gouty arthritis three weeks after operation, and after four months was admitted to hospital with cervical tuberculous lymphadenitis, which responded well to chemotherapy. Two of the three patients not belonging to the Watut area have been lost to follow-up. Thus of 11 patients followed for more than two months, eight were well and three had died-one as a direct result of operation and two from unknown causes.

\section{Effect of Splenectomy on the Haematological Findings}

In each case splenectomy was followed by a rise in haemoglobin (Table I). An initial temporary rise was related to blood transfusion and was followed by a gradual rise over several months (see Chant). Reticulocyte counts fell after one to two weeks to a mean of $1.4 \%$ (range 0.4 to $2.6 \%$ ). Howell-Jolly bodies and target cells were seen in the peripheral blood as early as 24 hours after operation. White cell counts rose promptly and a temporary leucocytosis often developed, final counts ranging from 6,000 to 19,700 (mean 10,600) $\mathrm{cu}$. $\mathrm{mm}$. Platelet counts rose in the first two weeks, in three cases to over $1,000,000 / \mathrm{cu}$. mm. and in one case to over $2,000,000 / \mathrm{cu}$. $\mathrm{mm}$., finally reaching a mean of $335,000 / \mathrm{cu}$. mm.

Red cell volume and red cell survival studies were repeated in three cases and normal values were obtained (Table II) except in Case 2, and this man was studied only 16 days after splenectomy, before equilibrium had been reached after massive blood loss and transfusion. Plasma volume studies were made in 10 cases at various times after splenectomy. There was a steep fall from the high preoperative level and a subsequent slow fall continuing over several months (see Chart). In the first four to eight weeks weight loss was marked (mean $5.9 \mathrm{~kg}$. for seven cases), but this was subsequently recovered, to result in a final gain in weight (mean $3.2 \mathrm{~kg}$. for five cases). Therefore the absolute plasma volume fell even more than is shown with the volume expressed in $\mathrm{ml} . / \mathrm{kg}$. of body weight.

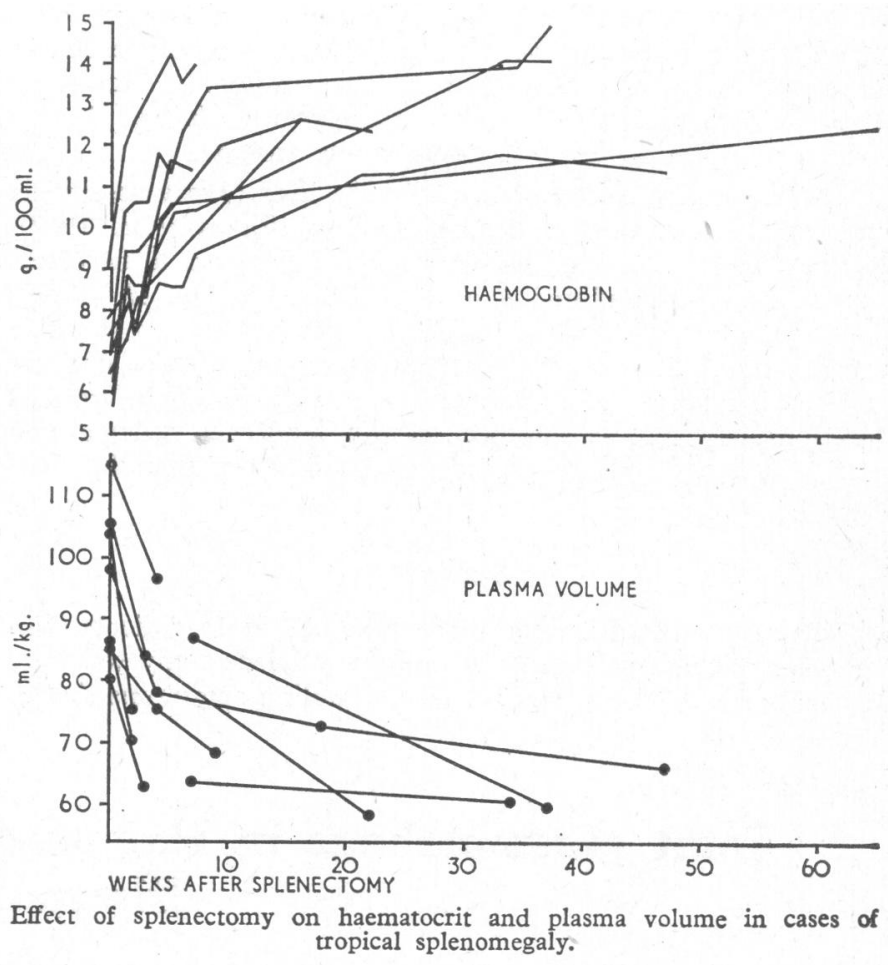

\section{Discussion}

In this group of patients with tropical splenomegaly, splenectomy produced correction of the anaemia and relief of symptoms. The main cause of the sustained rise in haemoglobin value was the progressive fall in plasma volume. Though increased red cell destruction occurred preoperatively and was corrected by splenectomy, haemolysis was not an important cause of anaemia, since the red cell volume was often raised and usually fell after splenectomy. The reason for the high plasma volume and its correction by splenectomy is not known. Similar results were recorded by McFadzean et al. (1958) in cryptogenic splenomegaly in Hong Kong and by Prankerd (1963) and Bowdler (1963) in patients with splenomegaly associated with blood disorders. In the present cases hypervolaemia was possibly related to hyperimmunity to malaria or other antigens causing increased rates of globulin synthesis. Splenectomy may have caused a decrease in globulin synthesis, giving rise to the fall in plasma volume. The lower red cell volume after splenectomy probably occurs because red cell production no longer has to maintain a large volume of cells in the splenic red cell pool (Prankerd, 1963 ; Weinstein, 1964 ; Pryor, 1967b). 
It is generally recognized that splenectomy, at least temporarily, increases susceptibility to bacterial infections (Lowdon et al., 1966) and in the present small series several infections occurred after splenectomy. The findings in a large number of splenectomies in Hong Kong were similar (Cook et al., 1963). The two patients who died suddenly in their villages some months after operation may have succumbed to overwhelming bacterial infections or to malaria. No clinical observations could be made during their fatal illnesses. Splenectomy alters the effective state of immunity to malaria, and in latent infections in experimental animals parasitaemia induced by splenectomy may persist for life (Garnham, 1963). Fatal Plasmodium falciparum malaria has been demonstrated after splenectomy in a previously immune chimpanzee (Rodhain and Jadin, 1964). $P$. vivax parasitaemia occurred in the postoperative period in one patient and some months after operation in two. Chloroquine tablets were given to each patient, with instructions that they be taken if fever occurred. Therefore little information concerning the hazards of malaria after splenectomy is provided. However, for cases from areas with endemic malaria and sporadic medical surveillance, splenectomy should probably be restricted to patients with disabling symptoms. Most persons with tropical splenomegaly are not greatly disabled despite their very large spleens and considerable anaemia.

The microscopical appearances of the liver biopsy specimens confirmed the absence of hepatic cirrhosis (Pitney et al., 1967), so that the results of operation might be expected to be better than those of Chaudhuri et al. (1956) and Cook et al. (1963), where many patients had cirrhosis. This latter study also showed much less mortality after splenectomy in those patients without cirrhosis. Hepatomegaly is usually found in tropical splenomegaly and, as jaundice, wasting, and even oedema may occur, it is difficult to exclude cirrhosis other than by liver biopsy.

\section{Summary}

The results of splenectomy are described in 15 patients with tropical splenomegaly in New Guinea. Splenectomy was performed only in those patients with disabling symptoms due to anaemia or the size and weight of the spleen. There was one operative death due to haemorrhage, and two other patients died suddenly some months after splenectomy.

The main cause of anaemia in this disorder was an expanded plasma volume, which was reduced after splenectomy. Increased red cell destruction was also corrected by splenectomy. There was a sustained rise in haemoglobin values, and the surviving patients have remained well over a short follow-up period. It is suggested that, until more information is available concerning the natural history of the disorder and the long-term results of splenectomy in regions where malaria is endemic and suppressive therapy difficult to administer, splenectomy should be reserved for patients with disabling symptoms.

I wish to thank Professor W. R. Pitney, of the University of New South Wales, for helpful advice and criticism; Dr. A. R. Shepherd, who performed the splenectomies; the Wellcome Trust for the provision of equipment; and Dr. R. F. R. Scragg, Director of Public Health, Territory of Papua and New Guinea, for making available facilities for this work.

\section{REFERENCES}

Atkinson, $M$, Sherlock, S. (1954). Lancet, 1, 1325.

Bowdler, A. J. (1963). Ann. intern. Med., 58, 664.

Chaudhuri, R. N., Saha, T. K., Basu, S. P., Mukherjee, A. M., and Chaudhuri, M. N. R. (1956). Indian f. med. Res., 44, 305.

Cook, J., McFadzean, A. J. S., and Todd, D. (1963).' Brit. med. F., 2, 337.

Crawford, H., and de Gruchy, G. C. (1958). Med. F. Aust., 1, 657. Dacie, J. V., and Lewis, S. M. (1963). Practical Haematology, 3rd ed.

Garnham P. C C. (1963). In Immunity to Protozoa, edited by P. C. C. Garnham, A. E. Pierce, and I. Roitt. London.

Hamila P. S et al. (1965). E. Afr. med. 7., 42, 196.

Hamilon, P. G. R., Stewart, R. H. M., and Walker, W. (1966). Brit. med. 7., $1,446$.

McFadzean, A. J. S., Todd, D., and Tsang, K. C. (1958). Blood, 13, 524 Pitney, W. R., Pryor, D. S., and Tait-Smith, A. (1967). F. Path. Bact. In press.

Prankerd, T. A. J. (1963). Brit. med. 7., 2, 517

Pryor, D. S. (1967a). Quart. F. Med., 36, 321

Pryor, (1967b). Ibid., 36, 337.

Rodhain J, and Jadin, (1964). Ann. Soc. belge Méd. trop., 44, 531.

Veall, N., and Vetter, H. (1958). Radioisotope Techniques in Clinical Research and Diagnosis. London.

Weinstein, V. F. (1964). Lancet, 2, 218.

\title{
Joint Haemorrhage in Haemophilia: Is Full Advantage Taken of Plasma Therapy?
}

\author{
ANITA M. ALI,* M.B., B.S.; K. H. GANDY,*† M.B., B.S. ; MARGARET I. BRITTEN,* B.SC. \\ KATHARINE M. DORMANDY,* M.B., M.R.C.P., M.C.PATH.
}

Brit. med.f., 1967, 3, 828-831

Recurrent bleeds into joints and muscles are among the most typical and frequent of the haemorrhages sustained by the severely affected haemophiliac (Wilkinson et al., 1961; Ramgren, 1962; Biggs and Matthews, 1966 ; Stuart et al., 1966 ; and many others). Without immediate and competent treatment these bleeds are potentially crippling, leading to various degrees of functional disability (Jordan, 1965a); their frequency makes adequate schooling practically impossible (Britten et al., 1966), thereby jeopardizing the boy's future career.

Despite the fact that plasma replacement therapy, given as soon as possible after the onset of bleeding, has for some years been the accepted treatment for musculoskeletal haemorrhage

\footnotetext{
- Department of Haematology, the Royal Free Hospital (North-western Branch), London N.W.3.

tPresent address: Department of Pathology, the Combined Cambridge Hospitals, Tennis Court Road, Cambridge.
}

(Biggs, 1964 ; van Creveld, 1964 ; Hardisty and Ingram, 1965 ; Salzman and Britten, 1965), it was apparent that many haemophiliacs in the Metropolitan Regional Hospital Board Areas were receiving inadequate treatment or none at all. A survey was therefore undertaken to ascertain the extent to which this treatment was in fact being used in that area. An attempt was also made to correlate the outcome of bleeds with the therapy that had been received. This paper describes our findings during 1965 and 1966.

\section{Materials and Methods}

The patients and their parents who took part in this investigation were already in touch with us through our survey into the educational problems of haemophiliacs. A total of 210 patients under the age of 30 ("boys"), registered at many different hospitals and all suffering haemarthroses, agreed to co-operate. 